\title{
Determination of Anterior Pelvic Index (API) to Predict a Narrow Pelvis in Adolescent Girls
}

\author{
Determinación del Índice Pelviano Anterior (API) para \\ Predecir Pelvis Estrecha en Adolescentes
}

Marco Guerrero,"**; Juan Ocampo*,***; Marcia Zapata***** \& Eduardo Yépez ${ }^{* * * * * *}$

GUERRERO, M.; OCAMPO, J.; ZAPATA, M. \& YÉPEZ, E. Determination of anterior pelvic index (API) to predict a narrow pelvis in adolescent girls. Int. J. Morphol., 34(3):1158-1163, 2016.

SUMMARY: Cephalopelvic disproportion in the pelvic inlet is a maternal risk factor in childbirth. A high number of dystocias are attended as emergencies and end in cesarean sections because there is no way to diagnose a narrow pelvis early on, a determination which would be easy to perform and at no cost to the patient. The aim of this study was to determine the Anterior Pelvic Index (API) as a predictive estimator of the obstetric conjugate diameter to differentiate narrow and normal pelvises. The study was conducted with 200 adolescent girls aged 14 to 19 years, from Quito, Ecuador; the parents signed the informed consent and the girls agreed to take part. The interspinous distance, height and obstetric conjugate diameter were measured by ultrasonography. Then the API was calculated and the predictive value of the obstetric conjugate diameter was obtained by simple linear regression. The average API value was 14.8 (CI $95 \%$ 14.75 to 14.86 ) with a minimum value of 13.99 and a maximum value of 19.92 . The association between the API and the obstetric conjugate diameter measured by ultrasonography produced a Pearson's correlation value of $0.543(\mathrm{p}=0.000)$. The simple linear regression test between the API and the obstetric conjugate diameter measured by ultrasonography was statistically significant. Therefore, it was determined that the prediction of the obstetric conjugate diameter, having the API as a predictor, can be calculated with the following formula: $y=4.38+0.45^{*} x$ and thus a possible narrow pelvis can be anticipated.

KEY WORDS: Pelvis; Pelvimetry; Narrow pelvis; Obstetric conjugate diameter.

\section{INTRODUCTION}

Maternal mortality is a huge public health issue in the world due to its repercussions on social development (Ministerio de Salud Pública, 2008). Pregnancy in adolescence is one of the high-impact risk factors for maternal mortality, not just because of the psychological and social implications it entails, but also because the organic structures are still developing, such as the uterus and its appendages and mainly the pelvic bone, whose ossification points finish consolidating at 20 years of age (Peláez Mendoza, 1997).

One of the aspects that increases risk in pregnancy is related to cephalopelvic disproportion, which is the third cause of Cesarean section in pregnant women under 20 (Guerra Verdecia et al., 2001; Fernández et al., 2004). The main origin in the mother's bone structure that causes this problem is a narrow pelvis (Murguía-González et al., 2013), which is usually detected by ultrasound in the last trimester of the pregnancy in the best case scenario; however, in most cases, the problem is observed only during delivery, leading to an emergency Cesarean section, risking the lives of both mother and child (Ruiz Prada, 2011). This is perhaps the most important risk factor of structural bone origin when deciding on the type of delivery to avoid a dystocia due to cephalopelvic disproportion (Vallejo Barón, 2013).

The term cephalopelvic disproportion is used to describe a disparity between the dimensions of the fetal head and maternal pelvis, which translates into a slowing or halting of cervical expansion and descent of the fetal head, despite

* Programa de Doctorado en Ciencias Morfológicas, Universidad de La Frontera, Temuco, Chile.

** M.D. Profesor de la Cátedra de Anatomía Normal. Carrera de Medicina. Universidad Central del Ecuador, Quito, Ecuador.

*** M.D. Profesor de la Cátedra de Histología Normal. Carrera de Medicina. Universidad Central del Ecuador, Quito, Ecuador.

**** Profesora de la Cátedra de Fisiología. Carrera de Medicina. Universidad Central del Ecuador, Quito, Ecuador.

****** M.D. Profesor de la Cátedra de Ginecología y Obstetricia. Carrera de Medicina. Universidad Central del Ecuador, Quito, Ecuador. 
the presence of adequate uterine contractions, thereby preventing a vaginal delivery (Piñango Cruz et al., 2006).

For many years, obstetricians have sought a way to measure the pelvic inlet in order to be prepared for a possible cephalopelvic disproportion. They began by measuring the pelvis indirectly through instrumental external pelvimetry; then, with the use of the pelvic $\mathrm{x}$-ray, the indirect measurement was put aside. However, the use of $x$-rays in pregnancy causes fetal genetic alterations that limit their practicality. With the advent of ultrasonography and magnetic resonance imaging (MRI), it became possible to measure the pelvic dimensions with great accuracy and to anticipate the risks of a dystocia (Benson \& Doubilet, 2014).

The cost of the technology is high, mainly if the desire is mass measurements with a preventive aim; therefore, it is necessary to investigate the creation of an index that can establish manually and indirectly the values of the dimensions of the pelvic outlet, mainly the obstetric conjugate diameter, which is the most sensitive in the diagnosis of a narrow pelvis (Aller \& Pagés, 1999).

The scientific literature has reported the index of the relative iliac bicrestal width to measure the pelvic inlet, but its measurement has two drawbacks: on the one hand, some people accumulate a considerable amount of adipose tissue in this zone, which makes it difficult to measure it exactly and, on the other, the iliac crest finishes ossifying at 23 years approximately; therefore, the values in adolescents can be vague (Hidalgo de Paz, 1997).

This study was conducted on adolescent girls aged 14 to 19 years residing in the urban parishes of the Distrito Metropolitano de Quito (DMQ), Ecuador, with the aim of determining the Anterior Pelvic Index (API) as a predictive estimator of the obstetric conjugate diameter to differentiate narrow and normal pelvises.

\section{MATERIAL AND METHOD}

This study was conducted with 200 adolescent girls, 14 to 19 years of age, born and residing in the Distrito Metropolitano de Quito (DMQ), Ecuador, from 35 high schools in the urban educational zones of the north, center and south of the district, who had not given birth; for those who had, the delivery was vaginal, with a normal pelvis, with no underlying pathology, who could take part in the study by their parents signing the informed consent and their own agreement. The study was approved by the Ethics Committee of the Universidad del Ecuador.
To calculate the sample size, the formula to calculate this for the determination of the correlation coefficient between variables was applied, and it was selected using two-stage probability cluster sampling.

In a health clinic, interviews were conducted and anthropometric measures were taken using a Health \& Meter Professional ${ }^{\circledR}$ scale with a height rod (Bridgeview, Illinois, USA), a Voluson E8 General Electric ultrasound (USA) and a Martin pelvimeter. A single investigator recorded the weight, height and interspinous distance, and another measured the obstetric conjugate diameter measured by ultrasonography. To this end, previously established measurement protocols were followed.

The values of the interspinous distance and height were measured in centimeters and subjected to a Pearson correlation analysis to determine their linear association. The Anterior Pelvic Index (API) was determined as follows:

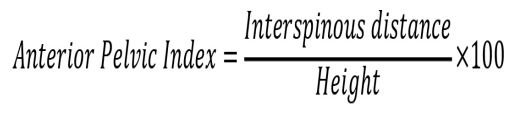

This result, like the value of the obstetric conjugate diameter, was used to construct a mathematical model, applying a simple linear regression to obtain a prediction value for the obstetric conjugate diameter by calculating coefficients of the linear regression line. An alpha error of 0.05 was used. The results were processed with IBM SPSS v22.

\section{RESULTS}

In order to determine the API, height and interspinous distance were used; in addition, obstetric conjugate diameter measured by ultrasonography was used to predict the true conjugate diameter. The mean of the height was $156.4 \mathrm{~cm}$ (CI $95 \% 155.6$ to 157.3), with the standard error of the mean being 0.43 , a variance of 37 and standard deviation of 6.1. The minimum height of the sample was $139 \mathrm{~cm}$ and the maximum was $181 \mathrm{~cm}$ with an interquartile range of 8.5 $\mathrm{cm}$. The coefficient of variation was 3.9. The measures of central tendency and dispersion, for each age, are shown in Table I.

The mean of the interspinous distance was $23.2 \mathrm{~cm}$ (CI $95 \% 23$ to 23.4), with a standard error of the mean of 0.1 , a variance of 1.7 and standard deviation of 1.3 . The resulting coefficient of variation was 5.7. The minimum value of this distance was $20 \mathrm{~cm}$ and the maximum value was $25.5 \mathrm{~cm}$. The interspinous distance of the adolescents according to age is shown in Table II. 
Table I. Measures of central tendency and dispersion of height $(\mathrm{cm})$ according to age (years) in adolescent girls in Quito, Ecuador.

\begin{tabular}{|c|c|c|c|c|c|c|c|}
\hline \multicolumn{2}{|l|}{ Age } & 14 & 15 & 16 & 17 & 18 & 19 \\
\hline \multicolumn{2}{|l|}{$\mathrm{n} / \%$} & $33 / 16.5$ & $31 / 15.5$ & $30 / 15$ & $28 / 14$ & $43 / 21.5$ & $35 / 17.5$ \\
\hline \multicolumn{2}{|l|}{ Mean } & 152.4 & 157.2 & 158.0 & 154.6 & 158.7 & 156.8 \\
\hline \multirow{2}{*}{ CI $95 \%$ for the mean } & Lower limit & 150.3 & 154.8 & 155.6 & 153 & 157.1 & 154.9 \\
\hline & Upper limit & 154.6 & 159.6 & 160.5 & 156.2 & 160.4 & 158.8 \\
\hline \multicolumn{2}{|l|}{ Variance } & 36.7 & 41.8 & 43.4 & 17 & 27.9 & 32.1 \\
\hline \multicolumn{2}{|l|}{ Standard deviation } & 6.1 & 6.5 & 6.6 & 4.1 & 5.3 & 5.7 \\
\hline \multicolumn{2}{|l|}{ Minimum } & 139 & 143 & 145 & 147 & 149 & 145 \\
\hline \multicolumn{2}{|l|}{ Maximum } & 165 & 173 & 181 & 162 & 177 & 169 \\
\hline \multicolumn{2}{|c|}{ Interquartile range } & 6 & 9 & 8 & 6.5 & 8 & 10 \\
\hline \multicolumn{2}{|c|}{ Standard error of the mean } & 1.1 & 1.2 & 1.2 & 0.8 & 0.8 & 1 \\
\hline \multicolumn{2}{|c|}{ Coefficient of variation. } & 4 & 4.1 & 4.2 & 2.7 & 3.3 & 3.6 \\
\hline
\end{tabular}

Table II. Measures of central tendency and dispersion of the interspinous distance $(\mathrm{cm})$ according to age (years) in adolescent girls in Quito, Ecuador.

\begin{tabular}{|c|c|c|c|c|c|c|c|}
\hline \multicolumn{2}{|l|}{ Age } & 14 & 15 & 16 & 17 & 18 & 19 \\
\hline \multicolumn{2}{|l|}{$\mathrm{n} / \%$} & $33 / 16.5$ & $31 / 15.5$ & $30 / 15$ & $28 / 14$ & $43 / 21.5$ & $35 / 17.5$ \\
\hline \multicolumn{2}{|l|}{ Mean } & 22.1 & 23 & 23.3 & 22.8 & 23.9 & 23.6 \\
\hline \multirow{2}{*}{ CI $95 \%$ for the mean } & Lower limit & 21.7 & 22.5 & 22.9 & 22.4 & 23.5 & 23.2 \\
\hline & Upper limit & 22.6 & 23.5 & 23.7 & 23.2 & 24.2 & 24.1 \\
\hline \multicolumn{2}{|l|}{ Variance } & 1.6 & 1.7 & 1.3 & 0.9 & 1.3 & 1.7 \\
\hline \multicolumn{2}{|l|}{ S tandard deviation } & 1.3 & 1.3 & 1.2 & 1 & 1.2 & 1.3 \\
\hline \multicolumn{2}{|l|}{ Minimum } & 20 & 20 & 21 & 21 & 21 & 21.5 \\
\hline \multicolumn{2}{|l|}{ Maximum } & 24.5 & 25.5 & 25.5 & 25 & 25.5 & 25.5 \\
\hline \multicolumn{2}{|l|}{ Interquartile range } & 2.3 & 1.5 & 1.5 & 1.5 & 2 & 2.5 \\
\hline \multicolumn{2}{|c|}{ S tandard error of the mean } & 0.2 & 0.2 & 0.2 & 0.2 & 0.2 & 0.2 \\
\hline \multicolumn{2}{|c|}{ Coefficient of variation. } & 5.7 & 5.7 & 5 & 4.2 & 5.5 & 5.5 \\
\hline
\end{tabular}

The mean of the obstetric conjugate diameter was $11.05 \mathrm{~cm}(\mathrm{CI} 95 \% 11$ to 11.1), with a standard error of the mean of 0.02 , a variance of 0.12 and standard deviation of 0.4. The coefficient of variation was 3.1. The minimum value of this diameter was $10 \mathrm{~cm}$ and the maximum value was $12 \mathrm{~cm}$. The measures of central tendency and dispersion of this diameter according to age were distributed as shown in Table III.
In order to determine the linear association between height and anterior transverse diameter, the Pearson correlation was used, the result of which was of 0.894 with a $p$ value $=0.000$. The value of the coefficient of determination was 0.799 .

The API for each subject was calculated and an average value of 14.8 (CI $95 \% 14.75$ to 14.86 ) was obtained,

Table III: Measures of central tendency and dispersion of obstetric conjugate diameter measured by ultrasonography according to age (years) in adolescent girls in Quito, Ecuador.

\begin{tabular}{|c|c|c|c|c|c|c|c|}
\hline \multicolumn{2}{|l|}{ Age } & 14 & 15 & 16 & 17 & 18 & 19 \\
\hline \multicolumn{2}{|l|}{$\mathrm{n} / \%$} & $33 / 16.5$ & $31 / 15.5$ & $30 / 15$ & $28 / 14$ & $43 / 21.5$ & $35 / 17.5$ \\
\hline \multicolumn{2}{|l|}{ Mean } & 10.8 & 11 & 11.2 & 11 & 11.2 & 11.1 \\
\hline \multirow{2}{*}{ CI $95 \%$ for the mean } & Lower limit & 10.6 & 10.9 & 11 & 10.9 & 11.1 & 11 \\
\hline & Upper limit & 10.9 & 11.2 & 11.3 & 11.1 & 11.3 & 11.3 \\
\hline \multicolumn{2}{|l|}{ Variance } & 0.1 & 0.1 & 0.1 & 0.1 & 0.1 & 0.1 \\
\hline \multicolumn{2}{|l|}{ Standard deviation } & 0.3 & 0.3 & 0.4 & 0.3 & 0.3 & 0.3 \\
\hline \multicolumn{2}{|l|}{ Minimum } & 10 & 10.2 & 10.5 & 10.5 & 10.6 & 10.5 \\
\hline \multicolumn{2}{|l|}{ Maximum } & 11.4 & 11.8 & 12 & 11.9 & 11.8 & 11.9 \\
\hline \multicolumn{2}{|l|}{ Interquartile range } & 0.5 & 0.4 & 0.4 & 0.4 & 0.4 & 0.5 \\
\hline \multicolumn{2}{|c|}{ Standard error } & 0.1 & 0.1 & 0.1 & 0.1 & 0.1 & 0.1 \\
\hline \multicolumn{2}{|c|}{ Coefficient of variation. } & 3.2 & 3.1 & 3.2 & 2.6 & 2.4 & 3 \\
\hline
\end{tabular}


with a standard error of the mean of 0.03 , a variance of 0.18 and a standard deviation of 0.42 . The coefficient of variation was 2.84. The minimum value of this index was 13.99 and the maximum value was 19.92 . The distribution of the measures of central tendency and dispersion of this index, according to age, is shown in Table IV.

A Pearson correlation was used to establish the linear association between the API and the obstetric conjugate diameter measured by ultrasonography, obtaining an $r$ value of $0.543(\mathrm{p}=0.000)$.

Taking the variable API as independent and the obstetric conjugate diameter measured by ultrasonography as dependent, these were subjected to a simple linear regression test, obtaining the following results: adjusted $\mathrm{R} 2$ value of 0.292 . Snedecor's F-distribution for the regression $=82.994 ; \mathrm{p}=0.000$. Non-standardized coefficient of the constant $=4.378$, a Student's t-value of 5.975; $\mathrm{p}=0.000$. Non-standardized coefficient of the independent variable $=0.451$, with a Student's t-value of $9.11 ; \mathrm{p}=0.000$.

The formula to predict the obstetric conjugate diameter, having the API as a predictor, is the following:

$$
y=4.38+0.45 * x
$$

Table IV. Measures of central tendency and dispersion of the Anterior Pelvic Index according to age (years) in adolescent girls in Quito, Ecuador.

\begin{tabular}{|c|c|c|c|c|c|c|c|}
\hline \multicolumn{2}{|l|}{ Age } & 14 & 15 & 16 & 17 & 18 & 19 \\
\hline \multicolumn{2}{|l|}{$\mathrm{n} / \%$} & $33 / 16.5$ & $31 / 15.5$ & $30 / 15.0$ & $28 / 14.0$ & $43 / 21.5$ & $35 / 17.5$ \\
\hline \multicolumn{2}{|l|}{ Mean } & 14.5 & 14.6 & 14.7 & 14.8 & 15 & 15.1 \\
\hline \multirow{2}{*}{ CI $95 \%$ for the mean } & Lower limit & 14.4 & 14.5 & 14.6 & 14.6 & 14.9 & 14.9 \\
\hline & Upper limit & 14.6 & 14.8 & 14.9 & 14.9 & 15.2 & 15.2 \\
\hline \multicolumn{2}{|l|}{ Variance } & 0.1 & 0.1 & 0.1 & 0.1 & 0.2 & 0.1 \\
\hline \multicolumn{2}{|l|}{ Standard deviation } & 0.3 & 0.3 & 0.4 & 0.3 & 0.4 & 0.4 \\
\hline \multicolumn{2}{|l|}{ Minimum } & 14 & 14 & 14 & 14.2 & 14.1 & 14.3 \\
\hline \multicolumn{2}{|l|}{ Maximum } & 15.2 & 15.4 & 15.6 & 15.6 & 15.9 & 15.7 \\
\hline \multicolumn{2}{|l|}{ Interquartile range } & 0.5 & 0.4 & 0.5 & 0.4 & 0.6 & 0.5 \\
\hline \multicolumn{2}{|c|}{ Standard error of the mean } & 0.1 & 0.1 & 0.1 & 0.1 & 0.1 & 0.1 \\
\hline \multicolumn{2}{|c|}{ Coefficient of variation. } & 2.3 & 2.3 & 2.5 & 2 & 2.9 & 2.5 \\
\hline
\end{tabular}

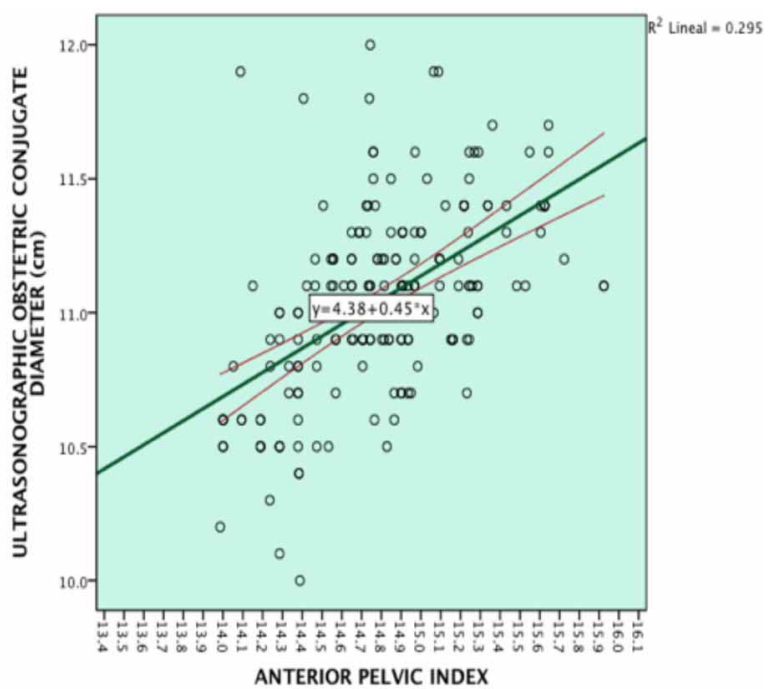

Fig. 1. Scatter plot with regression line between the values of the Anterior Pelvic Index and the obstetric conjugate diameter measured by ultrasonography, in 200 adolescent girls in Quito, Ecuador.

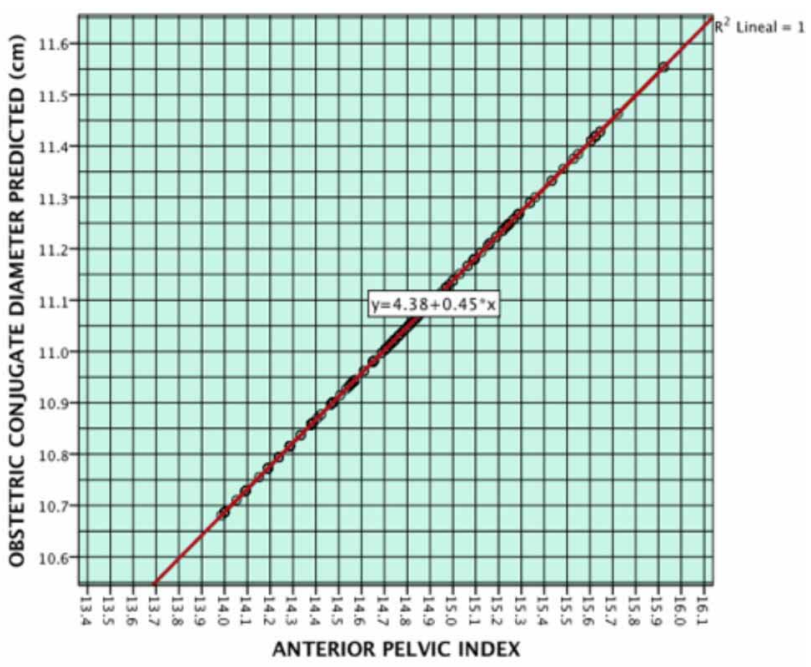

Fig. 2. Scatter plot with regression line between the values of the Anterior Pelvic Index and the predicted obstetric conjugate diameter measured by ultrasonography, in 200 adolescent girls in Quito, Ecuador. 


\section{DISCUSSION}

Pelvimetry is an important tool when it comes time to decide the type of delivery, mainly if there is a suspicion of dystocia, which involves the decision to perform a Cesarean section at the critical moment of an obstetric emergency. A common dystocia is cephalopelvic disproportion, which is linked to an increase in the risk of fetomaternal morbidity and mortality (Lenhard et al., 2010).

There have been very few scientific studies on external pelvimetry, perhaps because of today's modern technology like MRI, ultrasound 3D, digital tomography, etc. (Lenhard et al.); however, this technology is not always available or within reach at the right time, and there is no a protocol to indicate this type of imaging for a woman as routine to know the state of the pelvic inlet diameters.

According to Blanco Dávila (2005), there is a harmonic and symmetrical development of the human body; on the other hand, Sirvent Belando \& Garrido Chamorro (2009) reported the existence of a relation between the different anthropometric measures. Accordingly, the measurements taken using external pelvimetry make it possible to obtain, indirectly, the diameters of the internal pelvimetry, a principle that has motivated this study, using biostatistics as an important tool for calculation and prediction.

The interspinous distance was chosen as the measurement of external pelvimetry because it is more visible, stable and easy to measure; however, other pelvic points, like the highest point of the iliac crest, can be prone to error because, on many occasions, it is covered by abundant adipose tissue. The anterior transverse diameter measures obtained in this study $(23.2 \mathrm{~cm})$ are very similar to those reported by Guerrero \& Ocampo (2015) in adult women between 20 and 24 years $(23.5 \mathrm{~cm})$.

The obstetric conjugate diameter, which corresponds to internal pelvimetry, was selected because it represents the narrowest space of the initial part of the birth canal and can be easily measured by ultrasonography. The average value obtained in our study $(11.05 \mathrm{~cm})$ was lower than that reported by Vázquez-Barragán et al. (2016), whose average result in 290 female pelvises between 18 and 50 years of age, using computed tomography, was $11.73 \mathrm{~cm}$; in contrast, according to Guerrero \& Ocampo (2015) this diameter was $11 \mathrm{~cm}$.

The harmonic, symmetrical and proportionate development of the human body can be seen when the correlation between height and anterior transverse diameter is calculated, since a high, statistically significant $r$ value with a strong coefficient of determination was obtained. Thus, the results enabled the construction of the Anterior Pelvis Index (API).

The correlation between the API and the obstetric conjugate diameter measured by ultrasonography was positive and statistically significant. The essential part of this study consisted of finding an adjusted formula that can predict the value of the obstetric conjugate diameter through the API, which was achieved. There are no reports in the international scientific literature on anything similar.

In conclusion, the construction of the API is mathematically possible, given its strong positive correlation and its statistical significance. Therefore, the value of the obstetric conjugate diameter can be predicted to determine a narrow pelvis from the API using the formula obtained from a simple linear regression analysis.

\section{ACKNOWLEDGEMENTS}

To the students of the Medicine Program at the Universidad Central del Ecuador, especially to Mr. Bryan Cobeña and his colleagues, who actively participated in the logistical support of this study.

GUERRERO, M.; OCAMPO, J.; ZAPATA, M. \& YÉPEZ, E. Determinación del índice pelviano anterior (API) para predecir pelvis estrecha en adolescentes. Int. J. Morphol., 34(3):1158-1163, 2016.

RESUMEN : La desproporción feto-pélvica se puede producir en el estrecho superior de la pelvis, constituyéndose en un factor materno de riesgo en el parto. Un elevado número de partos distócicos son atendidos de emergencia y terminan en cesárea debido a que no existe un método de diagnóstico precoz de la estrechez pélvica, que sea fácil de realizar y sin costo para el paciente. El objetivo fue determinar el Índice Pelviano Anterior (API) como estimador predictivo del diámetro conjugado obstétrico para diferenciar pelvis estrechas y normales. El estudio fue realizado con 200 mujeres adolescentes de 14 a 19 años, de Quito, Ecuador, quienes cumplieron con la firma del consentimiento informado de los padres y el asentimiento de ellas. Se les midió la distancia interespinosa, la talla y el diámetro conjugado obstétrico ecográfico. Luego se calculó el Índice Pelviano Anterior y, mediante regresión lineal simple, se obtuvo el valor de predicción del diámetro conjugado obstétrico. El valor promedio del Índice Pelviano Anterior (API) fue de 14.8 (IC $95 \% 14.75$ a 14.86) con un valor mínimo de 13.99 y un valor máximo es de 19.92. La asociación entre el API y 
el diámetro conjugado obstétrico ecográfico produjo un valor de correlación de Pearson de 0.543 ( $\mathrm{p}=0.000)$. La prueba de regresión lineal simple entre el API y el diámetro conjugado obstétrico ecográfico fue estadísticamente significativo. Por lo tanto, se determinó que la predicción del diámetro conjugado obstétrico, teniendo como predictor al API, se calculará con la siguiente fórmula : $y=4.38+0.45^{*} x$ y con ello se podrá pronosticar una eventual estrechez pélvica.

PALABRAS ClAVE: Pelvis; Pelvimetría; Estrecho pélvico; Diámetro conjugado obstétrico.

\section{REFERENCES}

Aller, J. \& Pagés, G. Pelvis y Relación Feto-Pélvica. En: Aller, J. \& Pagés, G. (Eds.). Obstetricia Moderna, $3^{\text {rd }}$ ed. Ciudad de México, Mc Graw Hill - Interamericana, 1999. pp.109. Available from: http://www.fertilab.net/descargables/publicaciones/obstetricia_moderna/om_08.pdf

Benson, C. B. \& Doubilet, P. M. The history of imaging in obstetrics. Radiology, 273(2 Suppl.):S92-110, 2014.

Blanco Dávila, F. Las proporciones divinas. Cir. Plast., 15(2):11824, 2005.

Fernández, L. S.; Carro Puig, E.; Oses Ferrera, D. \& Pérez Piñero, J. S. Caracterización de la gestante adolescente. Rev. Cuba. Obstet. Ginecol., 30(2), 2004.

Guerra Verdecia, C. L.; Vázquez Márquez, A.; Herrera, V. V.; de la Cruz Chávez, F. \& Almirall Chávez, A. M. Embarazo y adolescencia: Factores biológicos materno y perinatal más frecuentes. Rev. Cuba. Obstet. Ginecol., 27(2):165-71, 2001.

Guerrero, M. \& Ocampo, J. Pelvis, Pelvimetría y Cavidad Pelviana. Quito, Markadigital, 2015. pp 30-56.

Hidalgo de Paz, A. Indice de anchura bicrestal ilíaca relativa como indicador de riesgo en el parto. Rev. Cuba. Obstet. Ginecol, 23(2):97-100, 1997.

Lenhard, M. S.; Johnson, T. R.; Weckbach, S.; Nikolaou, K.; Friese, K. \& Hasbargen, U. Pelvimetry revisited: analyzing cephalopelvic disproportion. Eur. J. Radiol., 74(3):e107-11, 2010.

Ministerio de Salud Pública. Plan Nacional de Prevención del Embarazo en Adolescentes en Ecuador. Quito, Gobierno Nacional de la República del Ecuador, 2008. Disponible en: http:/ /www.codajic.org/sites/www.codajic.org/files/ Plan $\% 20 \mathrm{Naciona1} \% 20 \mathrm{de} \% 20$ Prevenci\%C3\%B3n $\% 20 \mathrm{del} \% 20$ Embarazo\%20en\%20Adolescente\%20Ecuador.pdf

Murguía-González, A.; Hernández-Herrera, R. J. \& Nava-Bermea, M. Factores de riesgo de trauma obstétrico. Ginecol. Obstet. Mex., 81(6):297-303, 2013.
Peláez Mendoza, J. Adolescente embarazada: Características y riesgos. Rev. Cuba. Obstet. Ginecol., 23(1):13-7, 1997.

Piñango Cruz, P.; Rodríguez Penso, A.; Fajardo, J. F. \& Bello, F. Desproporción fetopélvica: Diagnóstico ecosonográfico. Rev. Obstet. Ginecol. Venez., 66(1):55-7, 2006.

Ruiz Prada, D. Indice Cefalopélvico en la Predicción de Parto Vaginal en Embarazadas Adolescentes. Tesis de Especialista en Ginecología y Obstetricia. Maracaibo, Universidad de Zulia, 2011.

Sirvent Belando, J. E. \& Garrido Chamorro, R. P. Valoración Antropométrica de la Composición Corporal. Cineantropometría. Alicante, Publicaciones Universidad de Alicante, 2009. pp.53-4.

Vallejo Barón, J. Embarazo en adolescentes complicaciones. Rev. Med. Costa Rica Centroam., 70(605):65-9, 2013.

Vázquez-Barragán, M. A.; Garza-Báez, A.; Morales-Avalos, R.; Martínez-González, B.; Jacobo-Baca, G.; Pinales-Razo, R.; Quiroga-Garza, A.; de la Fuente-Villarreal, D.; ElizondoRiojas, G.; Elizondo-Omaña, R. E. \& Guzmán-López, S. Pelvimetry by reformatted computed tomography in 290 female pelvis. Morphometric variations regarding age. Int. J. Morphol., 34(1):298-304, 2016.

\section{Corresponding to:}

Marco Guerrero

Profesor de la Cátedra de Anatomía Normal

Carrera de Medicina

Universidad Central del Ecuador

Quito

ECUADOR

Email: aguerrero@uce.edu.ec

Received: 29-07-2016

Accepted: 28-08-2016 